IRA-International Journal of Management \& Social Sciences

ISSN 2455-2267; Vol.10, Issue 03 (March 2018)

Pg. no. 107-118.

Institute of Research Advances

http://research-advances.org/index.php/RAJMSS

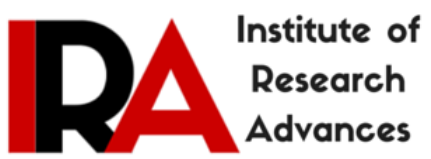

\title{
Computing Academics into New Age Programs and Fields: Big Data Analytics \& Data Sciences in Indian Academics-An Academic Investigation of Private Universities
}

\author{
P. K. Paul ${ }^{1 \#} \&$ P. S. Aithal ${ }^{2}$ \\ ${ }^{1}$ Raiganj University (RGU), West Bengal, India . \\ ${ }^{2}$ Vice Chancellor, Srinivas University, Karnataka, India..
}

\#corresponding author.

Type of Review: Peer Reviewed.

DOI: http://dx.doi.org/10.21013/jmss.v10.n3.p3

How to cite this paper:

Pal, P.K., Aithal, P.S. (2018). Computing Academics into New Age Programs and Fields: Big Data Analytics \& Data Sciences in Indian Academics-An Academic Investigation of Private Universities. IRA-International Journal of Management \& Social Sciences (ISSN 2455-2267), 10(3), 107-118. doi:http://dx.doi.org/10.21013/jmss.v10.n3.p3

(C) Institute of Research Advances.

\section{(c) $)$ BY-NC}

This work is licensed under a Creative Commons Attribution-Non Commercial 4.0 International License subject to proper citation to the publication source of the work.

Disclaimer: The scholarly papers as reviewed and published by the Institute of Research Advances (IRA) are the views and opinions of their respective authors and are not the views or opinions of the IRA. The IRA disclaims of any harm or loss caused due to the published content to any party.

Institute of Research Advances is an institutional publisher member of Publishers Inter Linking Association Inc. (PILA-CrossRef), USA. The institute is an institutional signatory to the Budapest Open Access Initiative, Hungary advocating the open access of scientific and scholarly knowledge. The Institute is a registered content provider under Open Access Initiative Protocol for Metadata Harvesting (OAI-PMH).

The journal is indexed \& included in WorldCat Discovery Service (USA), CrossRef Metadata Search (USA), WorldCat (USA), OCLC (USA), Open J-Gate (India), EZB (Germany) Scilit (Switzerland), Airiti (China), Bielefeld Academic Search Engine (BASE) of Bielefeld University, Germany, PKP Index of Simon Fraser University, Canada. 


\begin{abstract}
India is moving towards a developed country and thus knowledge cultivation is very much required and in this context introducing new age programs and degrees are essential. This is required for the creation of next generation skills and knowledge as per industrial and organizational demands including Government etc. Data Science is about managing the large amount and complex data, moreover, it is also known as Big Data Technologies. Due to the wider requirement in different universities and organizations, many international universities have started academic programs on Data Sciences and Big Data. However, a large number of institutes are located in India but only a few offer programs on Data Science and Allied Technologies. Importantly most these are listed in Engineering Colleges and few Private Universities. Universities in this regard adopted both fullfledged degrees and specialization methods to offer the Data Sciences and Allied Technologies. This paper is theoretical and contextual in nature, but also purely interdisciplinary in nature combines with education, information technology, and managerial science to learn about the status and future of qualified and skilled manpower. However, the paper is specially focused on private universities only with a brief overview of the technologies in international universities.
\end{abstract}

Keywords: Big Data, Data Sciences, Data Analytics, Private Universities, HEI, Indian Universities, R\&D, Research, Knowledge Economy.

\title{
Introduction
}

Data Science is an emerging academic field which purely deals with the Big Data Management and Analytics technologies. It is about managing large and numerous data and also complex data systems. Further it deals with the intelligent systems and information affairs. It is useful and required for almost all the purposes and settings viz. Government bodies, organizations, education systems, business and commercial places, healthcare and medicine and so on [1], [6]. Hence today companies and other establishments are also adopting analytics and big data systems for transformation of raw data into required information and easiness in decision making. Professional associated with this normally bears mixed of analytic, machine learning along with data mining skills. The reason behind the enhancement and popularity of the technologies include (but not limited to) -

- Helping and ensuring industrial knowledge viz. contextual understanding for a hidden solution to the business and organizations.

- Big Data Technologies and Management Systems today is in use of fields Organizational, Social, political, economic, legal, business, marketing for efficiency.

- Managing information explosion become easy with the adoption of Big Data Technologies and Management.

Initially, Data Science and Analytics were only available and started as a skill based program or area but gradually many international universities started educational programs in the field. Moreover, developing countries in recent past also moved into the field in their academia. As far as India is concerned, many educational institutes have started the program in the field particularly in Private Universities and Deemed Universities [1], [3], [7]. However, the growth of the program and field in Private Universities are catching.

\section{Objective and Agenda}

The core aim and agenda of this paper include (but not limited to) the following-

- To learn about the basics of Computing and Information Technology related subjects in brief with available programs.

- To know about the basics of emerging fields and areas of Computing or Information Sciences.

- To learn about the Data Science and Allied Technologies in brief with special reference to its characteristics.

- To know about the emerging educational programs in respect of Data Science and Allied Technologies in international universities, in brief. 
- To find out the basics of Higher Education Systems in India emphasizing Private Universities in India with brief statistics.

- To learn about the Data Science and Allied Technologies as educational programs in Indian Private Universities.

\section{Computing \& Academics: An Overview of Super Specialty Age}

Computing is a very vast field nowadays. It has increased in a rapid manner due to the information explosion and need of the information in the society at large. Due to this, several information centric domains and fields have been developed. Though initially, the first branch originated as Computer Science which has core focus of studying, designing and development of computer systems; thus it is hardware and mathematical in nature with a partial focus on Software Technologies/ Programming [2], [4], [6]. Though another limited branch called Computing/ Computer Systems is rather an application centric with a focus on Software Technologies [14]. However, it is important to note that another field called Computer Application has been developed in India with similarities in Computing/ Computer Systems. Computer Engineering though similar with the Computer Science but more focused on designing and development and programming languages. In Information space, among the domains important are Information Technology, which is concentrated with the information and combines with the components of Networking Technology, Database Technology, Multimedia Technology, Communication Technology apart from Software Technology which is the pillar of Computing/Computer Application and partially CS/CSE. Information Systems is another domain similar to the Information Technology but it has a focus on business and organizational uses and components of business into the program and domain. Information Science is another branch which is concentrated on information and IT application and integration in larger space include business houses, organizations, societal places etc [3], [5], [8]. However, apart from these few important areas, many merged domains also been developed viz.

- Informatics

- Knowledge Systems and Management

- Information Science and Technology or Information Science and Computing

- Computer and Information Science or Information and Computer Science

- Information Science and Systems etc.

\section{Big Data and Data Sciences: An Overview}

Big Data is an emerging branch today and mainly deals with processes to extract knowledge of structured or unstructured nature. Moreover, these are offered with few data analysis and tools as well such as statistics, data mining, and predictive. Probability models, pattern recognition are also important in Big Data Systems and it is also involved also with the areas of learning, visualization, machine learning, signal processing, statistical learning, database and mining, predictive analytics and databases, and so on [5], [7], [9]. The large amount of data affairs is called Big Data and organizations and institutions at large currently adopted Data Management benefits in different spaces [12], [13]. And it has become developed as a branch of study as well. Today many international universities have started programs and degrees on Big Data and allied subjects and among the subjects few important are-

- MSc-Data Science offered by Sheffield University, UK

- MSc-Data Science offered by University of Southampton, England

- MSc-Business Analytics offered by Imperial College, London

- MSc-Data Engineering offered by University of Dundee, UK

- MSc-Data Science offered by Edinburg Napier University, UK

- MSc-Data Science offered by Kings College, London

- MSc-Data Science offered by Goldsmith University of London, UK

- MSc-Big Data offered by University of Stirling, Scotland 
The ample job opportunities created the awareness about the area of Big Data and in many developed countries, various nomenclatures have been developed viz. Data Science, Big Data and Analytics Studies etc. Moreover UK has a well number of institutions/ programs in this regard [6], [10], [11].

\section{Data Science and Allied Technologies in Academics: A Study in Private Universities}

India is a leading higher education hub in the world with more than 40000 HEIs (Higher Educational Institutes). The body of HEIs consists of the universities, colleges, research centers, institutes of national importance etc. The Universities in India basically consist with the state universities, central universities, private universities, and deemed to be universities. Table: 1 depicted in Details on Private Universities in India.

Table: 1-Private Universities in India with distribution of Super Specialty Program in Data Sciences

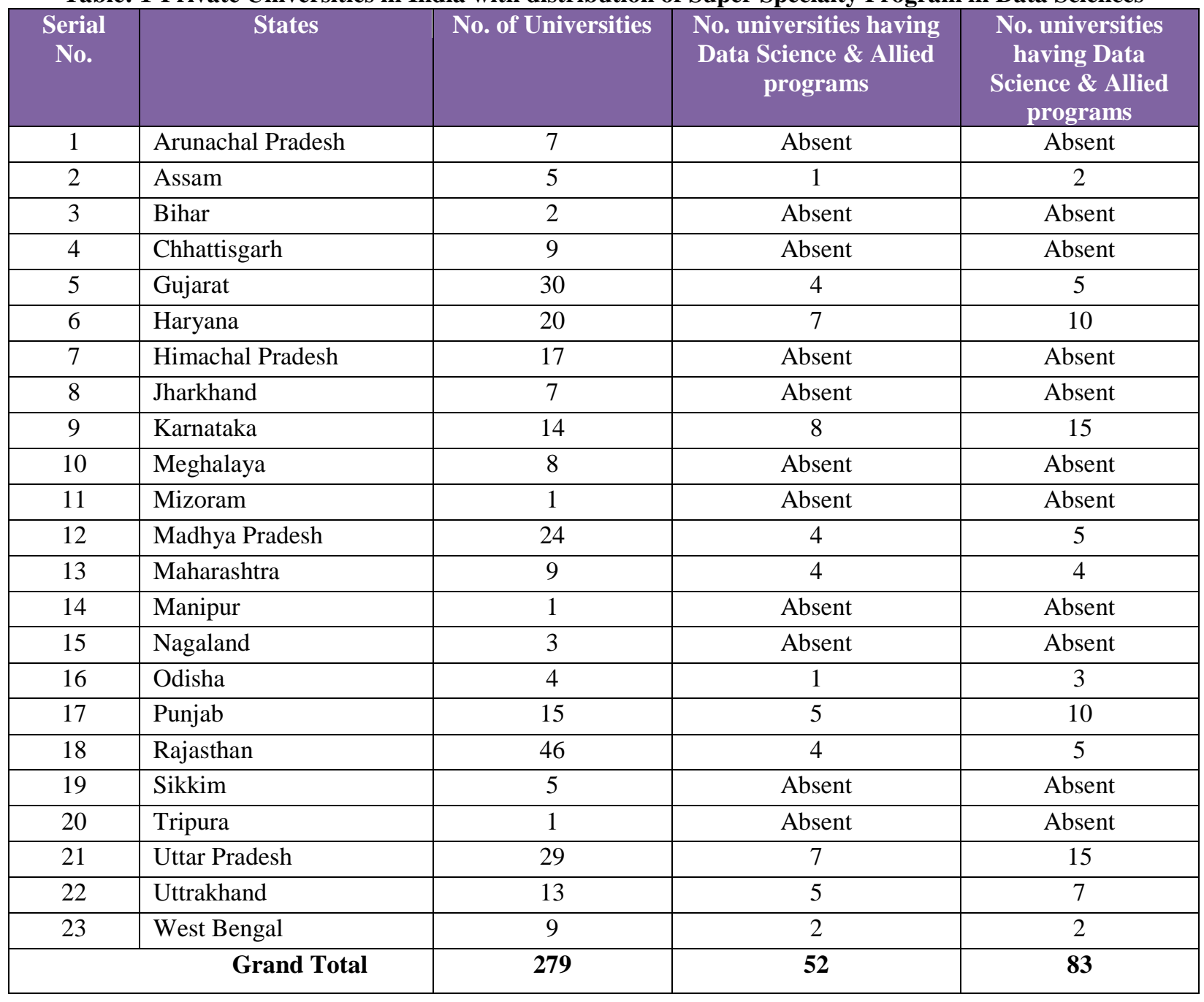

India holds 279 Private Universities (as on October, 2017) and in almost all the states having universities in this category except few states viz. Goa, Tamilnadu, Jammu \& Kashmir. Among the Indian states, Rajasthan holds first position with 46 (forty six) universities while Gujarat and Uttar Pradesh hold second and third positions with the number of universities 30 and 29 respectively. Importantly private universities are known for the specialty in various affairs viz. (but not limited to the) - 
- New educational methodologies in teaching

- Designing and development of new programs

- Interdisciplinary Programs

- Joint Degrees with Companies

- Joint Degrees with other institutions

- Joint and Integrated Degrees

- Collaboration with leading universities etc.

Importantly in respect of new age programs also private universities are well known and getting popularity. It is a fact that Information and Computing is a large field and it has two track 'Computing' and 'Information'. As far as new age programs within Information Science and Technology few important are include-

- Cloud Computing

- Virtualization

- Information Security

- Big Data Management

- Data Analytics

- Data Science

- Cyber Security and Forensic

- IT Infrastructure Management

In the field of Big Data, there are many related and allied subjects have been started as educational programs and among these few important are Data Analytics, Business Analytics, Big Data, Big Data Management, Data Science, Data Science and Engineering etc. It is worthy to mention that among the private universities offered or started the programs the degrees are with three main categories viz. Full-fledged Degrees, Major, Specializations, Minors in the concerned or allied fields viz.

- Data Analytics

- Business Analytics

- Big Data Big Data Management

- Data Science

- Data Science and Engineering

Table: 2 depict complete details on Data Science programs offered by the private universities in India according to the study conducted.

Table: 2-Private Universities in India emphasizing Super Specialty Program in Data Sciences

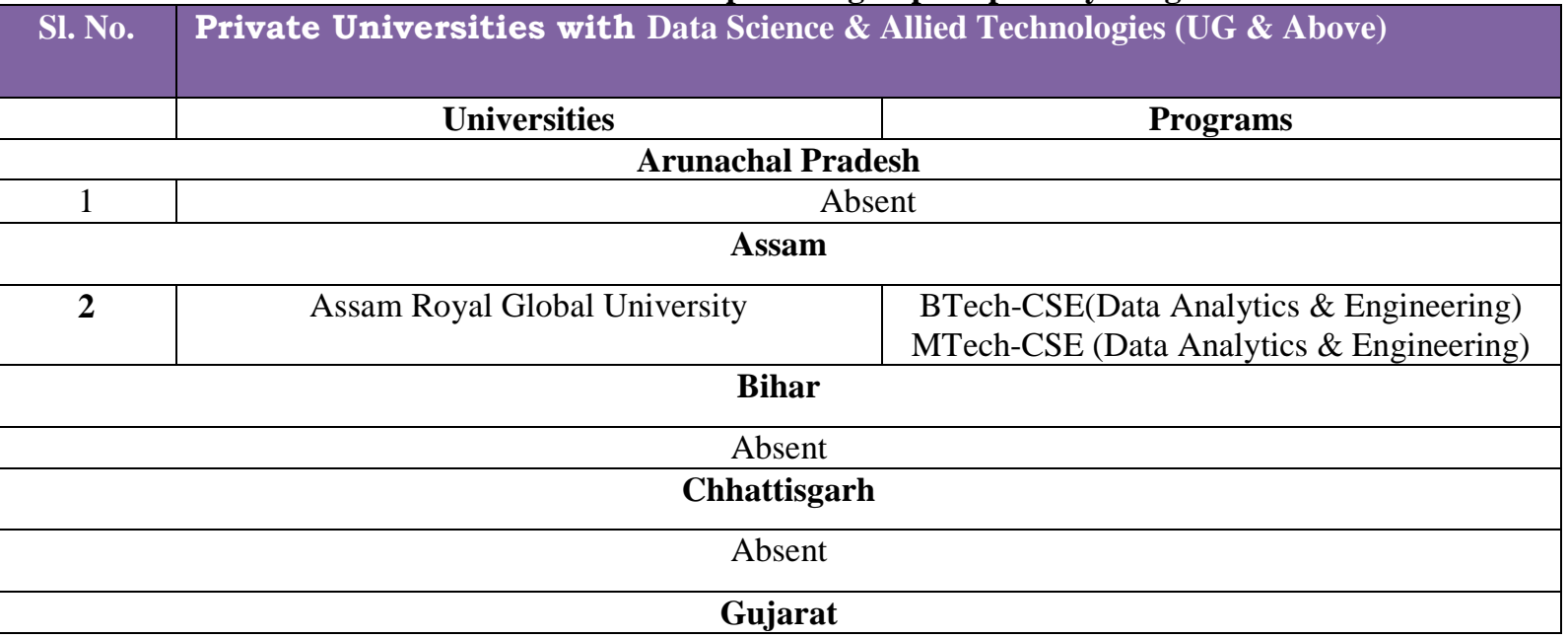


IRA-International Journal of Management E' Social Sciences

\begin{tabular}{|c|c|c|}
\hline 3 & Ahmadabad University & MTech CSE (Data Science \& Analytics) \\
\hline 4 & Ganpat University & $\begin{array}{l}\text { BTech- CSE (Big Data) } \\
\text { MTech-CSE (Big Data) }\end{array}$ \\
\hline 5 & G.L.S. University & MSc-IT (Data Analytics) \\
\hline & Navrachana University & MSc-IT (Database Administration) \\
\hline \multicolumn{3}{|c|}{ Haryana } \\
\hline 6 & Amity University & $\begin{array}{l}\text { BTech-(Data Science) } \\
\text { MTech-(Data Science) }\end{array}$ \\
\hline 7 & Ansal University & MTech-CSE (Data Analytics) \\
\hline 8 & O.P. Jindal University & MBA (Business Analytics with IBM) \\
\hline 9 & Jagan Nath University & $\begin{array}{l}\text { BTech-CSE (Business Analytics)-IBM } \\
\text { MBA (Business Analytics) with IBM }\end{array}$ \\
\hline 10 & PDM University & BTech-CSE (Big Data Analytics)-IBM \\
\hline 11 & $\begin{array}{c}\text { Shree Guru Gobind Singh Tricentenary } \\
\text { University }\end{array}$ & $\begin{array}{l}\text { BTech-CSE (Data Analytic) } \\
\text { MTech-CSE (Data Analytics) }\end{array}$ \\
\hline 12 & The Northcap University & MTech-CSE (Data Science) \\
\hline \multicolumn{3}{|c|}{ Himachal Pradesh } \\
\hline \multicolumn{3}{|c|}{ Absent } \\
\hline \multicolumn{3}{|c|}{ Jharkhand } \\
\hline \multicolumn{3}{|c|}{ Absent } \\
\hline \multicolumn{3}{|c|}{ Karnataka } \\
\hline 13 & CMR University & BBA (Business Analytics) \\
\hline 14 & Dayanand Sagar University & MTech- CSE (Big Data) \\
\hline 15 & Garden City University & BBA (Business Analytics) \\
\hline 16 & $\begin{array}{c}\text { Institute of Trans-Disciplinary Health Sciences } \\
\text { and Technology University }\end{array}$ & $\begin{array}{c}\text { MSc-CS CS (Data Analytics) } \\
\text { Integrated MSc-CS (Data Analytics) }\end{array}$ \\
\hline 17 & JSS Science \& Technology University & MTech-Data Science \\
\hline 18 & PES University & MTech-CSE (Big Data) \\
\hline 19 & Reva University & $\begin{array}{l}\text { BS-CS (Cloud Computing \& Big Data) } \\
\text { MTech- Data Engineering \& Cloud } \\
\text { Computing }\end{array}$ \\
\hline 20 & Srinivas University & $\begin{array}{c}\text { BCA (Data Analytics \& Cloud Computing) } \\
\text { Integrated MCA (4 Year) \& Trimester Based } \\
\text { (10+2 Any)- (With Specialization in Big Data) } \\
2 \text { Year } \\
\text { MCA (Related Degree)- With Specialization } \\
\text { in Big Data } \\
\text { MPhil (Data Analytics \& Cloud Computing } \\
\text { MPhil Business Analytics \& Cloud } \\
\text { Computing }\end{array}$ \\
\hline
\end{tabular}


IRA-International Joumal of Management E゚ Social Sciences

\begin{tabular}{|c|c|c|}
\hline & & $\begin{array}{c}\text { MPhil (Big Data \& Business Analytics) } \\
\text { MBA (Business Analytics) }\end{array}$ \\
\hline \multicolumn{3}{|c|}{ Meghalaya } \\
\hline \multicolumn{3}{|c|}{ Absent } \\
\hline \multicolumn{3}{|c|}{ Mizoram } \\
\hline \multicolumn{3}{|c|}{ Absent } \\
\hline \multicolumn{3}{|c|}{ Madhya Pradesh } \\
\hline 21 & Avantika University & BTech-CSE (Data Analytics) \\
\hline 22 & Jagran Lakecity University & MBA (Business Analytics) \\
\hline 23 & People's University & $\begin{array}{l}\text { BTech-CSE (Business Analytics) } \\
\text { BTech-IT (Business Analytics) }\end{array}$ \\
\hline 24 & Shri Vaishnav Vidyapeeth Vishwavidyalaya & BTech-CSE (Data Analytics)-IBM \\
\hline \multicolumn{3}{|c|}{ Maharashtra } \\
\hline 25 & Ajeenkya D.Y. Patil University & BTech-IT (Data Science) \\
\hline 26 & MIT Art Design \& Technology University & BTech-IT (Data Analytics) \\
\hline 27 & Sandip University & BTech-CSE (Business Analytics) \\
\hline 28 & Vishwarkarma University & MBA (Data Analytics) \\
\hline \multicolumn{3}{|c|}{ Manipur } \\
\hline \multicolumn{3}{|c|}{ Absent } \\
\hline \multicolumn{3}{|c|}{ Nagaland } \\
\hline \multicolumn{3}{|c|}{ Absent } \\
\hline \multicolumn{3}{|c|}{ Odisha } \\
\hline 29 & $\begin{array}{c}\text { Centurion University of Technology and } \\
\text { Management }\end{array}$ & $\begin{array}{c}\text { BTech-CS (Data Science)-Silicon Labs } \\
\text { MTech-Data Science (Silicon Lab) } \\
\text { MBA (Data Analytics) }\end{array}$ \\
\hline \multicolumn{3}{|c|}{ Punjab } \\
\hline 30 & Chandigarh University & $\begin{array}{c}\text { BE (Hons) CSE (Big Data)-IBM } \\
\text { ME (Hons) CSE (Big Data)-IBM } \\
\text { MBA-Business Analytics-IBM } \\
\end{array}$ \\
\hline 31 & CT University & MBA (Business Analytics) \\
\hline 32 & GNA University & BTech-Big Data Analytics \\
\hline 33 & Lovely Professional University & MBA (Business Analytics) \\
\hline 34 & Rayat Bahra University & $\begin{array}{c}\text { BCA Specialization- DBMS } \\
\text { MCA Specialization- DBMS } \\
\text { BTech (CSE)- Database \& Analytics (Oracle) } \\
\text { MBA (Business Analytics)-Google/ }\end{array}$ \\
\hline \multicolumn{3}{|c|}{ Rajasthan } \\
\hline 35 & J.K. Lakshmipat University & BTech-CSE (Big Data Analytics) \\
\hline 36 & Manipal University & $\begin{array}{l}\text { MTech-Advance Computing \& Data Science- } \\
\text { with CDAC }\end{array}$ \\
\hline 37 & Mody University of Science and Technology & $\begin{array}{c}\text { BTech-CSE (Big Data) } \\
\text { MBA (Business Analytics) }\end{array}$ \\
\hline 38 & NIIT University & MBA (Business Analytics (with WnS) \\
\hline \multicolumn{3}{|c|}{ Sikkim } \\
\hline \multicolumn{3}{|c|}{ Absent } \\
\hline \multicolumn{3}{|c|}{ Tripura } \\
\hline
\end{tabular}


IRA-International Journal of Management E' Social Sciences

\begin{tabular}{|c|c|c|}
\hline \multicolumn{3}{|c|}{ Absent } \\
\hline \multicolumn{3}{|c|}{ Uttar Pradesh } \\
\hline 39 & Amity University & $\begin{array}{l}\text { MTech-Data Science } \\
\text { PGD in Big Data }\end{array}$ \\
\hline 40 & Galgotias University & $\begin{array}{c}\text { MBA (Business Analytics) } \\
\text { BTech (H)-CSE (Data Analytics) } \\
\text { BTech (H)-CSE (Business Analytics } \\
\text { BTech (H)-CSE (Big Data) }\end{array}$ \\
\hline 41 & $\begin{array}{c}\text { Maharishi University of Information } \\
\text { Technology }\end{array}$ & $\begin{array}{c}\text { BTech-CSE (Data Analytics) } \\
\text { BSc-IT (Analytics \& Big Data) with related } \\
\text { paper } \\
\text { MSc-Analytics \& Big Data (Related \& } \\
\text { Relevant Degree including Economics) }\end{array}$ \\
\hline 42 & Sharda University & BTech-CSE (Business Analytics)-IBM \\
\hline 43 & Shiv Nadar University & $\begin{array}{c}\text { MSc-Data Analytics } \\
\text { PGD in Data \& Business Analytics }\end{array}$ \\
\hline 44 & Teerthanker Mahaveer University & MBA-Business Analytics-IBM \\
\hline 45 & The Glocal University & MBA (Business Analytics) \\
\hline \multicolumn{3}{|c|}{ Uttarkhand } \\
\hline 46 & DIT University & BTech-CSE (Big Data Analytics-IBM) \\
\hline 47 & University of Petroleum and Energy Studies & $\begin{array}{l}\text { BTech-CSE (Business Analytics-IBM) } \\
\text { BTech-CSE (Big Data with Xebia) }\end{array}$ \\
\hline 48 & Graphic Era Parvatiya Vishwavidyalaya & BTech-CSE (Big Data Analytics) \\
\hline 49 & Himalayan Garhwal University & MBA-Analytics Management \\
\hline 50 & Uttaranchal University & $\begin{array}{l}\text { BBA (Business Analytics-IBM) } \\
\text { MBA (Business Analytics-IBM) }\end{array}$ \\
\hline \multicolumn{3}{|c|}{ West Bengal } \\
\hline 51 & JIS University & MBA (Business Analytics) \\
\hline 52 & The Neotia University & BTech-CSE (Data Analytics)-IBM \\
\hline
\end{tabular}

It has been studied that among 279 private universities a significant growth has been carried in respect of offering programs in the field of Data Sciences. It is observed during this knowledge mapping that 52 universities offering programs in the field leading to Bachelors and Masters Degrees. However, as far as the numbers of programs are concerned in the field it is higher than that of the number of universities.

The study reveals that Karnataka and Uttar Pradesh hold first position regarding the offer of programs in Data and Allied Sciences with 15 (fifteen) UG/PG level of study. Whereas the second position holds Punjab and Haryana states with 10 (ten) programs each. 


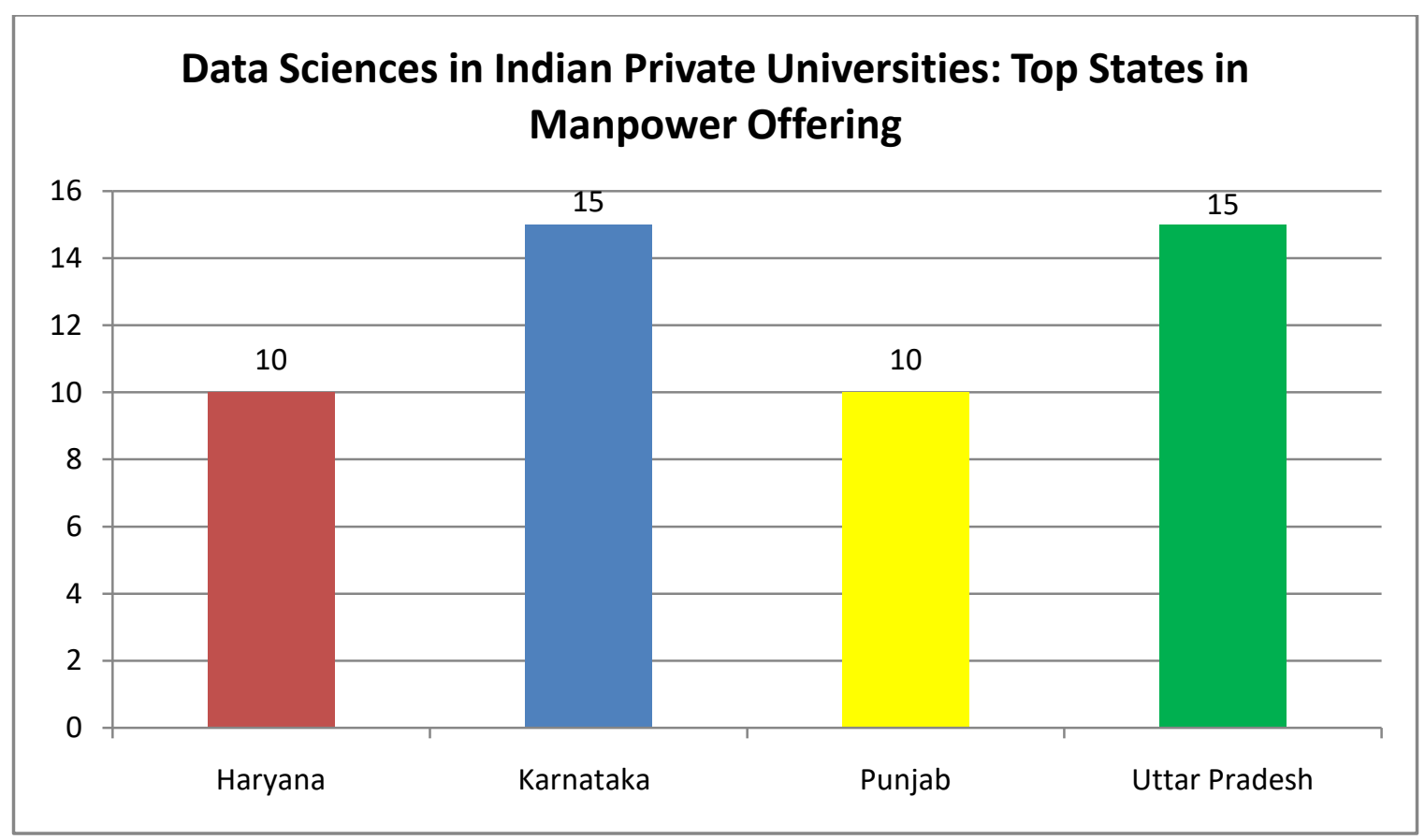

Fig:1- Top States having Private Universities in India on Super Specialty Programs in Data Sciences

It is worthy to note that among the programs on Data Science and Allied Technologies, these are offered in different track or flavor as well viz. within a program of Engineering, Science, and even in Management.

\section{Findings}

- Data related areas become subject and area nowadays and different nomenclatures are offered in different universities viz. Data Analytics, Business Analytics, Big Data, Big Data Management, Data Science, Data Science and Engineering.

- Data Science is a part of Technology and most specifically within Computing related Technology and it is also studied that in Computing related field 'Computer Application' subject is the important one. In the degrees on BCA and MCA also suitably Data Science Major may be incorporated and two universities among the private category have started this specialization (Refer Table: 3 )

- As a whole, the Data related subjects and areas called as Data Sciences and the private universities as per the concerned study offering the programs within Engineering and Technology track under the specializations of Computer Science and Engineering rather. While few universities have started Management track within MBA degree (refer Table: 4).

- Among the universities, it has noticed that Srinivas University, Maharishi University of Information Technology, Rayat Bahra University, Galgotias University etc offers a large number of programs in the field.

Table: 3-Private Universities started Data Science in Computer Application Track

\begin{tabular}{c|c|c|}
\hline $\begin{array}{c}\text { Sl. } \\
\text { No. }\end{array}$ & $\begin{array}{l}\text { Private Universities in India offering Data Science and Allied Technologies } \\
\text { Programs (Computer Application Track) }\end{array}$ \\
\hline 1 & Universities & Programs \\
\hline & Srinivas University & $\begin{array}{c}\text { BCA (Data Analytics \& Cloud Computing) } \\
\text { Integrated MCA (4 Year) \& Trimester Based (10+2 } \\
\text { Any)- (With Specialization in Big Data) }\end{array}$ \\
\hline
\end{tabular}


IRA-International Journal of Management E' Social Sciences

\begin{tabular}{|c|c|c|}
\hline & & $\begin{array}{c}\text { 2 Year } \\
\end{array}$ \\
& & $\begin{array}{c}\text { MCA (Related Degree)- With Specialization in Big } \\
\text { Data }\end{array}$ \\
\hline 2 & Rayat Bahra University & BCA Specialization- DBMS \\
& MCA Specialization- DBMS \\
\hline
\end{tabular}

Table: 4-Private Universities started Data Science in Management Track

\begin{tabular}{|c|c|c|}
\hline $\begin{array}{l}\text { Sl. } \\
\text { No. }\end{array}$ & $\begin{array}{l}\text { Private Universities in India offering } \\
\text { (Management Track) }\end{array}$ & Science and Allied Technologies Programs \\
\hline & Universities & Programs \\
\hline 1 & Jagan Nath University & MBA (Business Analytics) with IBM \\
\hline 2 & Garden City University & BBA (Business Analytics) \\
\hline 3 & Srinivas University & MBA (Business Analytics) \\
\hline 4 & Jagran Lakecity University & MBA (Business Analytics) \\
\hline 5 & Vishwarkarma University & MBA (Data Analytics) \\
\hline 6 & $\begin{array}{c}\text { Centurion University of Technology } \\
\text { and Management }\end{array}$ & MBA (Data Analytics) \\
\hline 7 & Chandigarh University & MBA-Business Analytics-IBM \\
\hline 8 & CT University & MBA (Business Analytics) \\
\hline 9 & Lovely Professional University & MBA (Business Analytics) \\
\hline 10 & Rayat Bahra University & MBA (Business Analytics)-Google \\
\hline 11 & $\begin{array}{c}\text { Mody University of Science and } \\
\text { Technology }\end{array}$ & MBA (Business Analytics) \\
\hline 12 & NIIT University & MBA (Business Analytics (with WnS) \\
\hline 13 & Galgotias University & MBA (Business Analytics) \\
\hline 14 & Teerthanker Mahaveer University & MBA-Business Analytics-IBM \\
\hline 15 & The Glocal University & MBA (Business Analytics) \\
\hline 16 & Himalayan Garhwal University & MBA-Analytics Management \\
\hline 17 & Uttaranchal University & $\begin{array}{l}\text { BBA (Business Analytics-IBM) } \\
\text { MBA (Business Analytics-IBM) }\end{array}$ \\
\hline 18 & JIS University & MBA (Business Analytics) \\
\hline
\end{tabular}

- Srinivas University, Karnataka holds first position with the highest number of programs in the field of Data Sciences and Allied Technologies. The university offers programs with BCA, MCA, Integrated MCA, and Three (3) MPhil program in the emerging field of study (Refer Table: 3). 


\section{Suggestion and Further Possibilities}

- Data Science and Allied Technologies in future may be started with the degrees as the Full-fledged way such as BSc/MSc-Data Science or Big Data or Allied Areas.

- The branch may be offered in collaboration with the industries for better job opportunities.

- The branch may be offered with Technology track for the degrees of BTech/BE and MTech/ME directly and as a Major.

- It is maybe also offered with the Degrees of MTech (Research) in Data Science and Technologies for the interested persons in research in the field.

- It has observed that Full-fledged MTech in Data Sciences (Coursework based) is still limited and the program may be offered with huge coursework for the concentration of industry and scientific bodies/ organization.

- Though two universities have started program of BCA in the field but it may be offered in the MCA program for better and more opportunities.

- Similar to private universities such subjects may be offered in other universities mainly central universities, state universities; as a good number of deemed universities already taken the initiative of the programs.

\section{Conclusion}

The world is changing rapidly and higher educational systems have been changed significantly in different occasion. There are tremendous changes and developments have been undertaken in the field of Computing and Informatics. It is worthy to note that the field has increased its scope and periphery significantly. In Information space, the development noticed in the creation of newer subjects viz. Informatics, Information Systems, Information Science, Information and Communication Technology. It is moreover gained reputation in recent past by the development of more new areas and super specialty areas like Cloud Computing, Virtualization, Information Security, Big Data Management, Data Analytics, Data Science, Cyber Security and Forensic, IT Infrastructure Management, User Experience Designing, Human Computer Interaction etc. Even due to their requirement in different settings most of these are offered as full-fledged subjects. As far as educational programs are concerned private universities in India also did a wonderful job by introducing new age, job ready and skill enhanced programs in the field. In future in different level also such programs may be started due to importance as a part of academic innovations.

\section{References}

[1] Altbach, P. G. (1993). The dilemma of change in Indian higher education. Higher Education, 26(1), 3-20.

[2] Chen, H., Chiang, R. H., \& Storey, V. C. (2012). Business intelligence and analytics: from big data to big impact. MIS quarterly, 1165-1188.

[3] Davenport, T. H., \& Patil, D. J. (2012). Data scientist. Harvard business review, 90(10), 70-76.

[4] Dumbill, E., Liddy, E. D., Stanton, J., Mueller, K., \& Farnham, S. (2013). Educating the next generation of data scientists. Big Data, 1(1), 21-27.

[5] Lyon, L., \& Brenner, A. (2015). Bridging the data talent gap: Positioning the iSchool as an agent for change. International journal of digital curation, 10(1), 111-122.

[6] Paul, P. K., \& Dey, J. L. (2017). Data Science Vis-à-Vis efficient healthcare and medical systems: A techno-managerial perspective. In Power and Advanced Computing Technologies (i-PACT), 2017 Innovations in (pp. 1-8). IEEE.

[7] Paul, P. K., Aithal, P. S. and A. Bhuimali, Enhancing Cloud and Big Data Systems for Healthy Food and Information Systems Practice: A Conceptual Study. International Journal of Scientific Research in Biological Sciences, 4(5), 18-22. ISSN : 2347-7520

[8] Paul, Prantosh Kumar and Aithal, P. S. and Bhuimali, A., Computing \& Allied Engineering Domain in India with Reference to Private Universities: A Case Study of Bachelors Programs. International Journal of Recent Researches in Science, Engineering \& Technology 5(11), 51-63. ISSN (Print): 2347-6729, (Indexed in Google Scholar, DIIF, SJIF). (UGC Serial Number: 45483)

[9] Paul, Prantosh and Aithal, P. S. and Bhuimali, A. and Kumar, K. (2017) Emerging Degrees and Collaboration: The Context of Engineering Sciences in Computing \& IT - An Analysis for Enhanced Policy Formulation in India. International Journal on Recent Researches In Science, Engineering \& Technology, 5(12), 13-27

[10] Paul, P. K., \& Ghose, M. K. (2018). A Novel Educational Proposal and Strategies Toward Promoting Cloud Computing, Big Data, and Human-Computer Interaction in Engineering Colleges and Universities. In Advances in Smart Grid and Renewable Energy (pp. 93-102) 
[11] Provost, F., \& Fawcett, T. (2013). Data science and its relationship to big data and data-driven decision making. Big data, 1(1), 51-59.

[12] Tang, R., \& Sae-Lim, W. (2016). Data science programs in US higher education: An exploratory content analysis of program description, curriculum structure, and course focus. Education for Information, 32(3), 269-290.

[13] Song, I. Y., \& Zhu, Y. (2016). Big data and data science: what should we teach?. Expert Systems, 33(4), 364-373.

[14] Varvel Jr, V. E., Bammerlin, E. J., \& Palmer, C. L. (2012). Education for data professionals: A study of current courses and programs. In Proceedings of the 2012 iConference (pp. 527-529). ACM. 